\title{
The HIV/AIDS Helpline Is an Effective Tool of Communication
}

\author{
Glory Alexander, Chitra L. Kanth, Priyanka Manoharan, Merlin Maria, Diptty Joseph \\ ASHA Foundation, Bangalore, India \\ Email: ashafblr@yahoo.co.in
}

Received 6 June 2014; revised 4 July 2014; accepted 1 August 2014

Copyright (C) 2014 by authors and Scientific Research Publishing Inc.

This work is licensed under the Creative Commons Attribution International License (CC BY).

http://creativecommons.org/licenses/by/4.0/

c) (i) Open Access

\begin{abstract}
Background and Objectives: With the evolution of mobile technology, the cell phone has become a medium of communication for all manner of diseases. So far no study has been done in India to assess the effectiveness of an AIDS Helpline and that too as a stand-alone service. The objective of this study was to determine if the callers to the HIV/AIDS Helpline found it to be an effective tool of communication. Methods: All the calls received on ASHA Foundation's HIV/AIDS manual helpline during the period of three years from April 2009 to March 2012, were included in this study. At the end of each call, the counselor asked the caller if he found the call useful and if so why he found it useful. If the caller did not find the call useful he also needed to say why he did not find it useful. Details of each call were recorded and entered on MS excel worksheet and finally analyzed using the SPSS software package. Results: The Helpline received 4692 calls during this period of which $90.9 \%$ calls were from males and $9.1 \%$ calls were from females. Of the 4692 calls, $38.72 \%$ were from repeat callers. Of the 2875 first time callers, $\mathbf{8 5 . 0 7 \%}$ responded and said that they found the helpline useful. Responses could not be elicited from the remaining $17 \%$ as the calls were disconnected before the question could be asked. Conclusions: Callers to the helpline were mostly male; $38.7 \%$ called again. All the callers who responded said that they found the helpline useful. Thus it is an effective tool of communication and could to be used to complement advanced care in HIV/AIDS.
\end{abstract}

\section{Keywords}

HIV/AIDS, Helpline, Communication, Effective

\section{Introduction}

According to the global UNAIDS report of 2010, an estimated 33.3 million people are living with HIV infection in the world. Of them, an estimated 2.4 million reside in India, making it the third largest country in the 
world for people living with HIV [1] [2]. HIV infection is entering into the fourth decade of existence, and yet, for countries situated in Middle-East Asia and South -East Asia, the issue of stigma and discrimination towards persons living with HIV/AIDS continues to remain a major issue. Even today, the sense of secrecy around HIV/AIDS remains unabated.

With the evolution of mobile technology, the cell phone has become a medium of communication for all manner of diseases including diabetes [3] cessation of smoking [4] minor depression [5] and rheumatoid arthritis [6]. The advantage of the cell phone is that it is easily accessible, it is under the control of the caller [6] and most importantly it maintains the anonymity and confidentiality of the caller. Various studies have shown that telephone counseling has been useful in enabling a caller to resolve issues and enable significant changes in behavior over a period of time [7]. A few studies have been done in the west and in Europe to assess the effectiveness of help lines from the callers' perspective and their satisfaction with such a service [8]-[10]. A study has been done in India to assess the efficacy of telephone based intervention in management of Rheumatoid Arthritis [6] that too as an adjuvant to clinical services. So far no study has been done in India to assess the effectiveness of an AIDS Helpline and that too as a stand-alone service.

ASHA Foundation, a Non Governmental Organization is located in Bangalore. The Foundation provides a range of services in the field of HIV/AIDS that includes awareness among vulnerable communities, adolescent health education in schools, care and support services for HIV infected persons including provision of anti-retroviral treatment, Prevention of Mother To Child Transmission of HIV (PMTCT Services), empowerment of HIV infected and affected women through provision of knowledge, job placements, microcredit facilities and formation of Self Help Groups, capacity building and research. The Foundation established the first HIV/AIDS Helpline for the state of Karnataka in 1998. The initial helpline consisted of an Interactive Voice Response System that led the caller through a series of options through the usage of buttons. However, in the year 2000, ASHA Foundation also introduced the manual telephone counseling line for HIV/AIDS. A paper describing the profile of the callers using the helpline was published in the year 2011 [12]. That study revealed that the main users of the HIV/AIDS Helpline are urban, young, educated males.

The objective of this study was to determine whether the caller from his perspective found the HIV/AIDS Helpline to be an effective tool of communication and whether it satisfied his need to call the helpline.

\section{Material and Methods}

The HIV/AIDS helpline of ASHA Foundation is located in the urban district of Bangalore.

The HIV/AIDS helpline functions on five days of the week from 9.00 am to $5.00 \mathrm{pm}$. There are two manual helplines. Three trained and qualified counselors respond to all the calls on the manual telephone line. The availability of this service is advertised via newspapers, radio, mobile phones, yellow pages, directories, posters and online. It is important to remind the public at regular intervals that such a service is available.

All the calls received on our manual helpline during the period of three years from April 2009 to March 2012, were included in this study. Confidentiality of each caller was maintained. Each call varied in length from a few minutes to almost forty five minutes depending on the need of the caller. Once a rapport was established, general details such as age and occupation of the caller were noted. At the end of each call, the counselor asked the caller if he found the call useful and if so why he found it useful. If the caller did not find the call useful he also needed to say why he did not find it useful. Details of each call were recorded and entered on MS excel worksheet and finally analyzed using the SPSS software package.

\section{Results}

During this period of three years, there was a total of 4692 calls made to the helpline. As observed in our previous paper [12] a majority of the callers were male and less than ten percent were female (Tables 1-3).

Of the 4692 calls received, 1817 (38.7\%) were from callers who had called the helpline previously.

Figure 1 depicts the reasons for calling the helpline. Forty six percent of the callers called for information on HIV/AIDS. Thirty two percent called for risk that they had subjected themselves to and were worried about the consequences. Almost fifteen percent of callers called regarding care and support services available for HIV/ AIDS. Therefore almost ninety three percent of the calls were for information on HIV/AIDS, risk related to HIV/AIDS and on care and support services for HIV/AIDS. Many callers who called the helpline with regard 
Table 1. Distribution of calls by gender.

\begin{tabular}{ccccc}
\hline Total no. of calls & Male callers & Percentage & Female callers & Percentage \\
\hline 4692 & 4266 & $90.9 \%$ & 426 & $9.1 \%$ \\
\hline
\end{tabular}

Table 2. Distribution of new and repeat calls.

\begin{tabular}{ccccc}
\hline & Male & Female & Total & $\%$ \\
\hline New & 2656 & 219 & 2875 & 61.27 \\
Repeat & 1610 & 207 & 1817 & 38.72 \\
Total & 4266 & 426 & 4692 & 100.00 \\
\hline
\end{tabular}

Table 3. Usefulness of the helpline.

\begin{tabular}{ccc}
\hline YES & Response could not be elicited & Total \\
\hline 2446 & 429 & 2875 \\
$85.07 \%$ & $17.53 \%$ & $100 \%$ \\
\hline
\end{tabular}

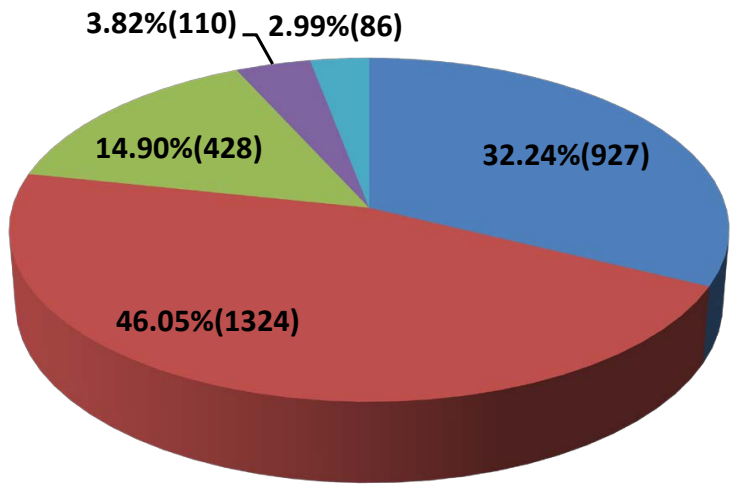

\author{
Risk \\ - Information Related to \\ HIV/AIDS \\ - Care \& Support \\ Sex \& Sexuality \\ Not Related to HIV/AIDS
}

Figure 1. Reason for calling the helpline (new callers).

to risk, never expressed their risk at the beginning of the call but tended to digress on other aspects of HIV/AIDS such as modes if transmission and treatment available and once they felt comfortable with the counselor they expressed their risk. Other callers called for issues related to sex and sexuality, and some calls were for information or services not related to HIV/AIDS.

Of the 2875 callers who called the helpline for the first time, the counselors were able to elicit responses from 2446 callers. Four hundred and twenty nine callers disconnected the call before the counselors could ask the question about whether they found the call useful. All the remaining 2446 callers said that they found the helpline useful. They said that they were able to get adequate responses to their queries and in some cases even more then what they had asked for. There were no callers who said that the call was not useful.

Table 4 depicts the distribution of responses by the counselors to the callers. The responses are more than the number of calls to the helpline, and this is because though the caller called for a particular reason such as risk activity, the counselor realized that the caller did not have adequate information on HIV/AIDS and therefore provided this information also. The counselor had to address more issues than what the caller had called for. A new category added to this list is emotional support. Many calls were from persons who had indulged in a risk activity and were nervous, fearful and anxious about whether they had become HIV positive. The counselor had to provide emotional support to such callers. Only $7.8 \%$ of the calls translated into drop-in visit to the counseling center at ASHA Foundation. Around 92\% of the calls were sorted out on the telephone itself.

Of the 4692 calls received during the study period, $38.72 \%$ of the calls were from repeat callers. The distribution of calls between new callers and repeat callers is shown in Table 5. 
Table 4. Categorisation of responses by the counselors.

\begin{tabular}{|c|c|c|c|c|c|c|c|}
\hline Risk & $\begin{array}{c}\text { Information } \\
\text { Related to } \\
\text { HIV/AIDS } \\
\end{array}$ & $\begin{array}{c}\text { Sex \& } \\
\text { Sexuality }\end{array}$ & $\begin{array}{l}\text { Care \& } \\
\text { Support }\end{array}$ & Emotional Support & $\begin{array}{l}\text { Not Related to } \\
\text { HIV/AIDS }\end{array}$ & $\begin{array}{c}\text { Call Translated to } \\
\text { Face to Face } \\
\text { Counseling } \\
\end{array}$ & Total \\
\hline 848 & 1938 & 104 & 347 & 316 & 75 & 225 & 3853 \\
\hline
\end{tabular}

Table 5. Distribution of calls between new callers and repeat callers.

\begin{tabular}{|c|c|c|c|}
\hline Reason for Calling the Helpline & $\begin{array}{l}\text { New Callers } \\
\text { N-2875 (\%) }\end{array}$ & $\begin{array}{c}\text { Repeat Callers } \\
\mathrm{N}-1817(\%)\end{array}$ & P Value \\
\hline Care and support for HIV/AIDS & 459 (15.97) & $496(27.30)$ & $<.0001$ \\
\hline Information on HIV/AIDS & $1283(44.63)$ & $1060(58.34)$ & $<.0001$ \\
\hline Risk related to HIV & 931 (32.38) & $203(11.17)$ & $<.0001$ \\
\hline Sex and sexuality & $108(3.76)$ & $38(2.09)$ & .0014 \\
\hline Not related to HIV/AIDS & $94(3.27)$ & $20(1.10)$ & $<.0001$ \\
\hline
\end{tabular}

\section{Discussion}

In our study, there are several indicators to show that the HIV/AIDS helpline is an effective tool for communication. Of the 2446 first time callers who responded to the question of whether they found the helpline useful, all of them said that they found the helpline useful. Besides, thirty-eight percent of our callers were repeat callers. This showed that they were comfortable with calling the helpline and knew that their further queries would be responded to. Most of the repeat callers called with relation to further information on HIV/AIDS or for further information on care and support services. Very few repeat callers called for risk, sex and sexuality or for information not related to HIV/AIDS. These observations are statistically significant as shown in Table 5 demonstrating that the type of call is dependent on whether it is a first time caller or a repeat caller. A third indicator is that only $7.8 \%$ of the calls actually resulted in a visit to the counseling center of ASHA Foundation, indicating that many issues for which the callers called the helpline could be resolved on the telephone itself. The telephone helpline could be used as a stand-alone service. Now that it is known that the helpline is an useful tool of communication, its use can be extended to beyond just provision of information, emotional support or care and support services. In India, a study was done to determine the impact of telephonic reinforcement on quality of life in patients with heart failure [11].

In the west, its use in the field of HIV/AIDS has been quite advanced. The telephone has been used for case finding through anonymous telephone interviews asking details of sexual practices to enable screening for HIVrelated risk [13]. In the west, helplines have also been used to provide information on clinical trials in the field of HIV/AIDS [14]. Many persons living with HIV infection and their families depend on this telephone-based service to decide about options in management of their HIV disease. In India, it has been useful for young males who have been at risk and who want information and HIV testing to be done with confidentiality [12]. Sometimes when they have to wait for testing because the window period is not over, and they are anxious and worried, they use the helpline for emotional support. Persons Living with HIV (PLHIV) call the helpline for information on care and support services. Initially they may not express that they are HIV positive but as they find that the counselor is helpful, friendly, non-judgemental, they begin to confide in the counselor about their status and request for further help with regard to more information on HIV/AIDS, supportive counseling, medical care, testing of other family members, anti retroviral therapy, names of facilities where support services are available etc. For those on Anti-Retroviral Therapy (ART), helplines can be used to reinforce adherence [15]. Helplines also are useful for HIV positive pregnant mothers who want to know how to prevent transmission to their babies and they can also be used for emotional support to such mothers. They can complement Prevention of Mother to Child Transmission services. Another use is in the case of occupational risk such as needle stick injury. Here the knowledgeable counselor can calm down the anxious caller who has had a needle stick injury and then help the counselee proceed with the steps that need to be taken in the management of post exposure prophylaxis. Of course, the involvement of the hierarchy in the institution where the needle stick injury has occurred is mandatory, but in many instances the management in the institution itself may not know what needs to be done and in 
such cases the helpline is a good source of information. Further, besides providing the initial support to both the injured employee and the Institution, the helpline then becomes a source of support to the employee in later days as he/she waits for the first HIV test to be done after several weeks and requires emotional support. Currently in the era of pre-exposure prophylaxis, (PrEP) information regarding this can be imparted to non-infected partners as a first step.

Overall the telephone help lines remain an useful and effective mode of communication in healthcare.

\section{References}

[1] (2013) UNAIDS Global Report 2010. www.unaids.org

[2] (2013) NACO Website, Annual Report 2008-09. www.nacoonline.org

[3] Leggett-Frazier, N., Swanson, M.S., Vincent, P.A., Pokorny, M.E. and Engelke, M.K. (1997) Telephone Communications between Diabetes Clients and Nurse Educators. The Diabetes Educator, 23, 287-293. http://dx.doi.org/10.1177/014572179702300307

[4] Zhu, S., Tedeschi, G.J., Anderson, C.M. and Pierce, J.P. (1996) Telephone Counseling for Smoking Cessation: What's in a Call? Journal of Counseling \& Development, 75, 93-102. http://dx.doi.org/10.1002/j.1556-6676.1996.tb02319.x

[5] Lynch, D.J., Tamburrinom, B. and Nagel, R. (1997) Telephone Counseling for Patients with Minor Depression: Preliminary Findings in a Family Practice Setting. The Journal of Family Practice, 44, 293-298.

[6] Hughes, R.A., Carr, M.E., Huggett, A. and Thwaites, C.E.A. (2002) Review of the Function of a Telephone Helpline in the Treatment of Outpatients with Rheumatoid Arthritis. Annals of the Rheumatic Diseases, 61, 341-345. http://dx.doi.org/10.1136/ard.61.4.341

[7] Reese, R.J., Conoley, C.W. and Brossart, D.F. (2006) The Attractiveness of Telephone Counseling: An Empirical Investigation of Client Perceptions. Journal of Counseling and Development, 84, 54-60. http://dx.doi.org/10.1002/j.1556-6678.2006.tb00379.x

[8] Picciano, J.F., Roffman, R.A., Kalichman, S.C. and Walker, D.D. (2007) Lowering Obstacles to HIV Prevention Services: Effects of a Brief, Telephone-Based Intervention Using Motivational Enhancement Therapy. Annals of Behavioral Medicine, 34, 177-187. http://dx.doi.org/10.1007/BF02872672

[9] Reese, R.J., Conoley, C.W. and Brossart, D.F. (2002) Effectiveness of Telephone Counseling: A Field-Based Investigation. Journal of Counseling Psychology, 49, 233-242. http://dx.doi.org/10.1037/0022-0167.49.2.233

[10] Bos, A.E.R., Visser, G.C., Tempert, B.F. and Schaalma, H.P. (2004) Evaluation of the Dutch AIDS Information Helpline: An Investigation of Information Needs and Satisfaction of Callers. Patient Education and Counseling, 54, 201206. http://dx.doi.org/10.1016/S0738-3991(03)00214-3

[11] Ramachandran, K., Husain, N., Maikhuri, R., Seth, S., Vij, A., Kumar, M., et al. (2007) Impact of a Comprehensive Telephone-Based Disease Management Programme on Quality-of-Life in Patients with Heart Failure. The National Medical Journal of India, 20, 67-73.

[12] Alexander, G., Kanth, C. and Thomas, R. (2011) A Descriptive Study on the Users and Utility of the HIV/AIDS Helpline in Karnataka, India. Indian Journal of Community Medicine, 36, 17-20. http://dx.doi.org/10.4103/0970-0218.80787

[13] Montgomery, K., Lewis, C.E. and Kirchgraber, P. (1991) Telephone Screening for Risk of HIV Infection. Medical Care, 29, 399-407. http://dx.doi.org/10.1097/00005650-199105000-00001

[14] Capitanio, J.P. and Herek, G.M. (1999) AIDS-Related Stigma and Attitudes toward Injecting Drug Users among Black and White Americans. American Behavioral Scientist, 42, 1148-1161. http://dx.doi.org/10.1177/00027649921954813

[15] Cook, P.F., McCabe, M.M., Emiliozzi, S. and Pointer, L. (2009) Telephone Nurse Counseling Improves HIV Medication Adherence: An Effectiveness Study. Journal of the Association of Nurses in AIDS Care, 20, 316-325. http://dx.doi.org/10.1016/j.jana.2009.02.008 
Scientific Research Publishing (SCIRP) is one of the largest Open Access journal publishers. It is currently publishing more than 200 open access, online, peer-reviewed journals covering a wide range of academic disciplines. SCIRP serves the worldwide academic communities and contributes to the progress and application of science with its publication.

Other selected journals from SCIRP are listed as below. Submit your manuscript to us via either submit@scirp.org or Online Submission Portal.
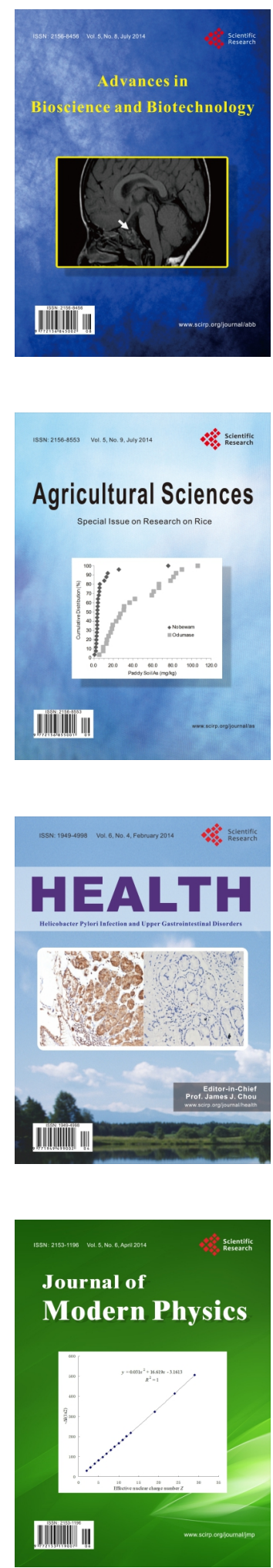
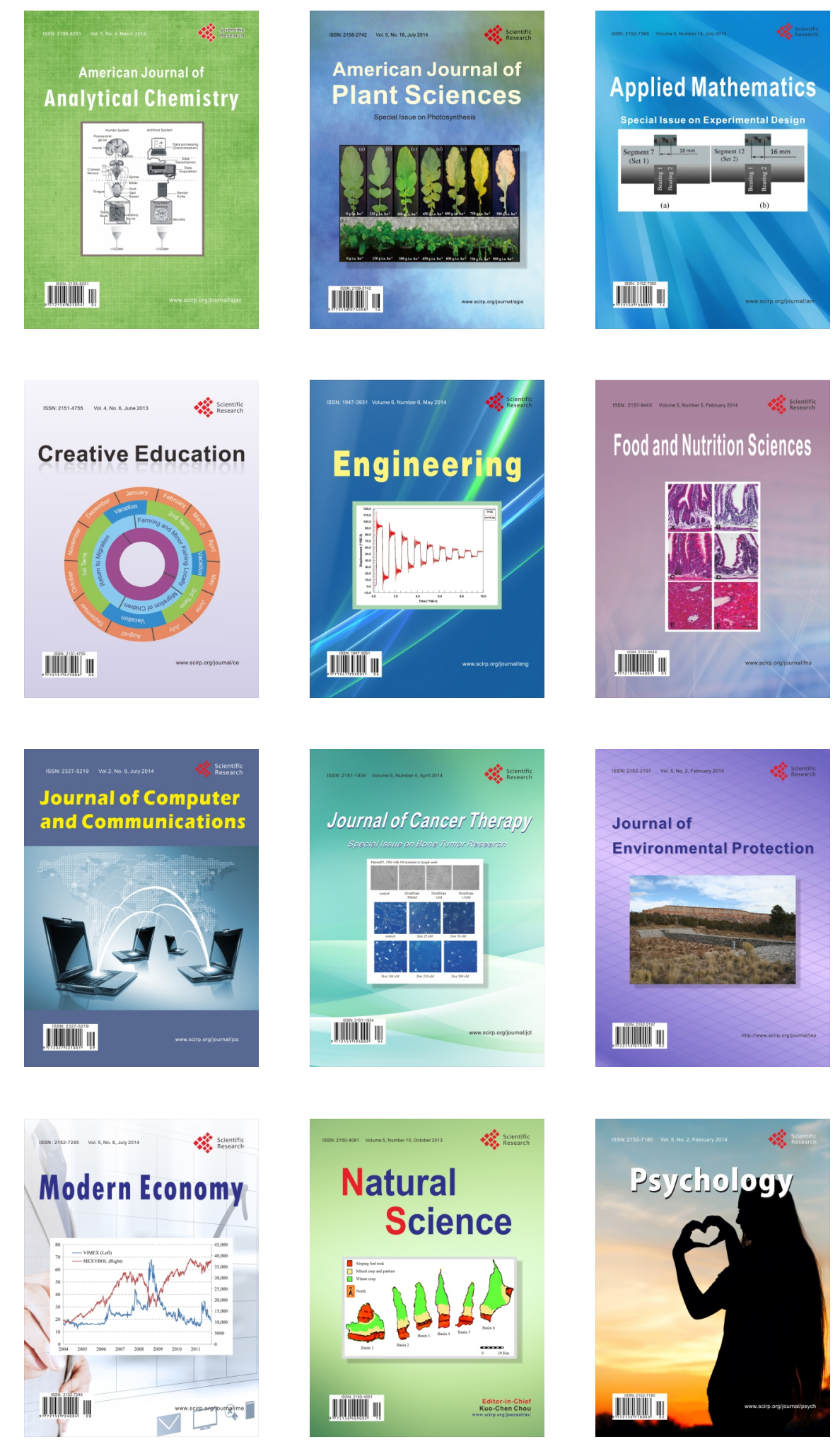